\title{
KOMUNIKASI PEMASARAN DIGITAL UMKM DESA TRIDAYA SAKTI SEBAGAI WUJUD LITERASI DIGITAL UMKM
}

\author{
Dewi Rachmawati ${ }^{1}$, Riska Afrianti $^{2}$, Stephanny Lianardo ${ }^{3}$ \\ ${ }^{1,2}$ Fakultas Ilmu Komunikasi - Institut Komunikasi dan Bisnis LSPR \\ Fakultas Bisnis - Institut Komunikasi dan Bisnis LSPR \\ dewi.r@1spr.edu, riska.a@1spr.edu, stephanny.1@1spr.edu
}

\begin{abstract}
Abstrak
Gerakan literasi digital saat ini sedang digencarkan pemerintah ke semua lapisan masyarakat. Dengan adanya gerakan ini, diharapkan masyarakat tidak hanya melek teknologi dan dapat menggunakannya, namun juga memahami dan memiliki kecakapan digital serta bertanggung jawab dalam penggunaannya. Salah satu lingkup yang menjadi sasaran literasi digital adalah UMKM (Usaha Mikro, Kecil dan Menengah) terutama di desa. Dari sisi komunikasi pemasaran, digitalisasi ini dilakukan agar UMKM dapat naik tingkat dan dapat menjangkau pemasaran yang lebih luas dengan waktu lebih cepat serta efektif dan efisien. Institut Komunikasi dan Bisnis LSPR, turut berperan dalam percepatan literasi digital bagi UMKM ini dengan mengadakan workshop melalui media online bagi UMKM Desa Tridaya Sakti Kecamatan Tambun Selatan, Kabupaten Bekasi. Sebanyak 11 UMKM dari desa ini hadir pada workshop yang mengangkat judul Komunikasi Pemasaran Usaha dan Jasa Melalui Media Sosial pada Kelompok Usaha di Desa Tridaya Sakti. Peserta UMKM menyadari peran penting komunikasi pemasaran melalui media sosial, yang saat ini dapat menjangkau pelanggan dengan lebih cepat. Namun dalam penerapannya masih ada beberapa kendala yang dialami seperti kurangnya kecakapan dalam penggunaan teknologi dan pemahaman mengenai konten media sosial itu sendiri, foto produk dan koneksi internet. Peserta juga terdorong dan akan menggunakan media sosial untuk mendukung komunikasi pemasaran usaha mereka.
\end{abstract}

Kata kunci : komunikasi pemasaran digital, literasi digital, UMKM

PENDAHULUAN

Gerakan literasi digital saat ini sedang digaungkan pemerintah terutama melalui Kementerian Komunikasi dan Informatika Republik Indonesia. Gerakan ini tidak hanya menyasar masyarakat di kota-kota besar saja, namun diharapkan dapat menjangkau hingga pelosok nusantara. Gerakan literasi digital ini diluncurkan secara masif oleh Menteri Komunikasi dan Informatika, Johnny G Plate pada tanggal 16 April
2021 dengan sasaran 12,4 juta masyarakat Indonesia (Kementerian Komunikasi dan Informatika Republik Indonesia, 2021). Gerakan ini menjangkau seluruh lapisan dan kelompok masyarakat serta dari segala usia di seluruh nusantara. Gaungan gerakan literasi digital oleh pemerintah ini selaras dengan temuan penelitian oleh Arianto (2020) yang menunjukkan bahwa dukungan pemerintah terhadap digitalisasi UMKM dapat mendorong percepatan proses transformasi digital dan ekonomi di 
Indonesia hingga bahkan nantinya dapat menjadikan UMKM Indonesia untuk bersaing dalam lingkup Internasional.

Data We are Social dan Hootsuite yang dirilis pada Januari 2021 menyebutkan bahwa terdapat kenaikan sebesar $15,5 \%$ atau sebesar 27 juta pengguna internet di Indonesia dibandingkan setahun sebelumnya, yakni dibagnding Januari 2020. Kenaikan ini cukup besar dibandingkan kenaikan global yang hanya sekitar 7,3\%. Hal ini menunjukkan pengguna internet di Indonesia cukup besar dibandingkan kenaikan pengguna internet dunia secara keseluruhan (We are Social, 2021). Jumlah pengguna internet tersebut adalah yang menjadi sasaran Gerakan literasi digital, termasuk di dalamnya adalah UMKM (Usaha Mikro, Kecil dan Menengah).

Usaha Mikro, Kecil dan Menengah (UMKM) juga merupakan sasaran dari Gerakan Literasi Digital. Data dari Badan Pusat Statistik menunjukkan jumlah UMKM di Indonesia mencapai angka 64 juta yang mana mencakup sebanyak $99,9 \%$ dari total usaha yang beroperasi di Indonesia. (Santia, 2020). Pertumbuhan UMKM yang begitu besar ini juga seyogyanya diimbangi dengan digitalisasi UMKM sehingga UMKM Indonesia dapat maju dan bersaing dengan negara lain serta dapat mendukung pertumbuhan ekonomi Indonesia.

UMKM merupakan kependekan dari Usaha Mikro, Kecil dan Menengah. Menurut Tambunan (2012), UMKM adalah unit usaha produktif yang berdiri sendiri, yang dilakukan oleh orang perorangan atau badan usaha di semua sektor ekonomi. Pada prinsipnya, pembedaan antara Usaha Mikro (UMI), Usaha Kecil (UK), Usaha Menengah (UM), dan Usaha Besar (UB) umumnya didasarkan pada nilai aset awal (tidak termasuk tanah dan bangunan), omset rata-rata per tahun, atau jumlah pekerja tetap. Namun definisi UMKM berdasarkan tiga alat ukur ini berbeda menurut negara. Karena itu, memang sulit membandingkan pentingnya atau peran UMKM antar negara.

$\begin{array}{rccc}\text { Badan } & \text { Pusat } & \text { Statistik } & \text { (BPS) } \\ \text { menggolongkan } & \text { UMKM } & \text { menjadi } & \text { empat }\end{array}$
berdasarkan jumlah tenaga kerja yang dimiliki.
Yang pertama adalah industry rumah tangga apabila memiliki tenaga kerja antara 1 sampai 4 orang. Kedua adalah industri kecil dengan jumlah tenaga kerja antara 5 sampai dengan 9 orang. Ketiga adalah industry sedang/menengah apabila memiliki tenaga kerja antara 10 hingga 99 orang. Terakhir adalah industry besar apabila memiliki jumlah tenaga kerja lebih dari 100 orang (Budiarto, et al, 2015)

Pandemi Covid-19 yang melanda Indonesia bahkan dunia mendorong transformasi digital di Indonesia, tak terkecuali dengan UMKM Indonesia. Kondisi pandemi Covid-19 yang membatasi pertemuan fisik masyarakat membuat penjual termasuk UMKM baik produk maupun jasa berpikir kreatif agar tetap eksis. Kegiatan interaksi jual beli yang biasanya dilakukan tatap muka langsung, sekarang dibatasi dan memaksa untuk dilakukan secara daring ataupun kegiatan fisik terbatas. Kebanyakan UMKM yang semula masih melakukan transaksi secara fisik dan kesulitan untuk bertransformasi ke digital, tidak jarang gulung tikar dengan kondisi pandemi ini.

Institut Komunikasi dan Bisnis LSPR, mengambil bagian dalam percepatan digitalisasi UMKM ini dengan mengadakan workshop berbasis online bagi UMKM Desa Tridaya Sakti, Kecamatan Tambun, Kabupaten Bekasi. Workshop ini mengangkat judul "Komunikasi Pemasaran Usaha dan Jasa Melalui Media Sosial pada Kelompok Usaha di Desa Tridaya Sakti, Kecamatan Tambun Selatan, Kabupaten Bekasi”. Kegiatan workshop melalui media online ini berfokus pada pelatihan pemanfaatan media sosial sebagai media pemasaran, terutama dalam bentuk komunikasi pemasaran yang mana mencakup strategi dan perencanaan konten media sosial.

Institut Komunikasi dan Bisnis LSPR sebelumnya juga pernah melaksanakan kegiatan Pengabdian Kepada Masyarakat dalam bentuk penghargaan dan pelatihan kepada Culinary Entrepreneur yang mana merekomendasikan penggunaan media sosial Instragram dengan memanfaatkan komunikasi pemasaran digital yang efektif berguna untuk meningkatkan omzet suatu UMKM. (Prasetyawati, Setyaningtyas, Ayu, Sartika, \& Adithia, 2021).

\begin{tabular}{l|l} 
Teknologi Informasi dan Komunikasi & 31
\end{tabular} 
Penekanan pada pelatihan komunikasi pemasaran ini juga didukung oleh temuan penelitian yang pernah sebelumnya terlaksana yang menunjukkan bahwa literasi digital pemilik UMKM terkait penggunaan media sosial secara teknis sudah baik namun dari segi pengembangan konten masih belum maksimal dan perlu ditingkatkan. (Sasmito \& Prestianto, 2021).

Selain itu, merujuk pada hasil penelitian oleh Sari, Yunizar, dan Sartika (2020) menunjukkan bahwa kompetensi dalam literasi digital mempunyai pengaruh pada keunggulan suatu usaha dalam bersaing, dalam hal ini juga mencakup UMKM. Oleh karena itu, diharapkan dari kegiatan ini, UMKM Desa Tridaya Sakti tergerak untuk beralih digital dalam pemasaran produknya dan tentu saja dengan penggunaan perangkat dan aplikasi yang bertanggung jawab.

\section{METODE}

Pelaksanaan kegiatan pengabdian kepada masyarakat ini mengikuti rangkaian metode pelaksanaan yang terdiri atas tiga bagian, yakni tahap persiapan, pelaksanaan kegiatan, dan tahapan pasca kegiatan. Pada tahap persiapan, ada beberapa hal yang dilakukan, diawali dengan mengomunikasikan rencana kegiatan kepada mitra kegiatan, dalam hal ini adalah Kepala Desa Tridaya Sakti, Bapak Suwardi Wada, S.E. Tim pelaksana berkoordinasi dengan Kepala Desa Tridaya Sakti untuk mengumpulkan data calon peserta pemilik UMKM di desa Tridaya Sakti yang mana akan dihubungi oleh tim panitia untuk diundang menghadiri kegiatan workshop dengan media online. Pada saat menghubungi calon peserta untuk ikut mendaftar dalam kegiatan workshop dengan media online ini, calon peserta juga diminta untuk mengisi serangkaian pertanyaan sebagai pre-test sebagai salah satu data untuk mengukur efektivitas kegiatan pengabdian kepada masyarakat ini. Selain itu, tahap persiapan ini juga meliputi persiapan materi untuk topik workshop, yakni Pelatihan Komunikasi Pemasaran untuk UMKM melalui media sosial, dan juga persiapan secara teknis dikarenakan kegiatan berlangsung secara daring menggunakan media online.

Tahap berikutnya, yakni pelaksanaan kegiatan, mencakup jalannya kegiatan workshop dengan media online. Kegiatan workshop berlangsung pada Kamis, 5 Agustus 2021 pada pukul 10.00-12.00 WIB secara daring menggunakan layanan platform ZOOM. Kegiatan berlangsung secara daring dikarenakan situasi pandemi mengikut terbitnya Instruksi Mendagri Nomor 27 Tahun 2021 terkait perpanjangan Pemberlakuan Pembatasan Kegiatan Masyarakat Level 4, Level 3, dan Level 2 COVID-19 di wilayah Jawa dan Bali. Kegiatan ini dihadiri oleh 11 peserta UMKM dan 93 peserta mahasiswa. Kehadiran peserta mahasiswa ini terkait kegiatan lanjutan yang mana mahasiswa akan membantu membuat rencana komunikasi sosial media untuk peserta UMKM dalam bentuk ajang perlombaan. Para narasumber yang terlibat dalam kegiatan ini adalah Bapak Resiyaman $P$. Oratmangun, SE, BAIB, MIB sebagai pemateri utama, Bapak Agus Dwi Riyanto, ST, M.Si., Kepala Bidang Usaha Kecil dan Menengah Kabupaten Bekasi menggantikan Kepala Dinas yang tidak bisa hadir, serta Bapak Suwardi Wada, SE, selaku Kepala Desa Tridaya Sakti, dengan Dr. Lestari Nurhajati, M.Si., selaku moderator acara.



Gambar 1. Poster Kegiatan Acara 


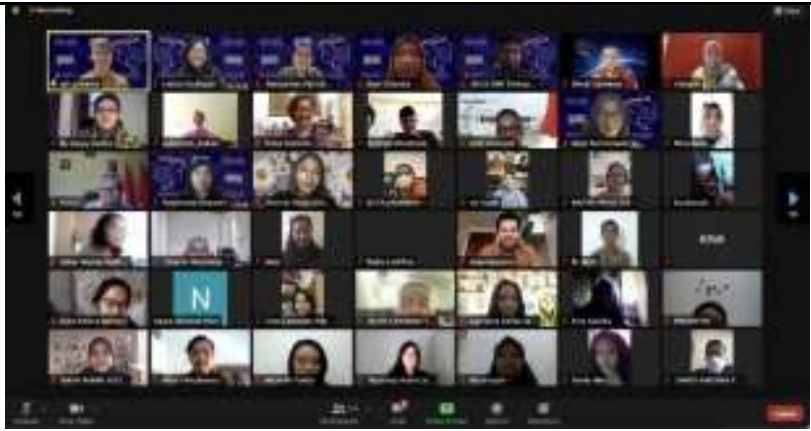

Gambar 2. Foto pada saat acara berlangsung

Setelah kegiatan workshop melalui media online berakhir, maka pelaksanaan masuk ke tahap terakhir yakni pasca kegiatan. Dalam tahap ini, pihak panitia menghubungi peserta UMKM yang hadir dalam kegiatan workshop untuk mengisi survei post-test sebagai bagian dari evaluasi kegiatan yang dituangkan dalam bentuk laporan kegiatan. Selain pembuatan laporan kegiatan, tahapan ini juga mencakup publikasi kegiatan workshop yang mana kegiatan workshop melalui media online ini telah dipublikasikan sebanyak 19 publikasi oleh media online dan 1 oleh media cetak.

\section{HASIL DAN PEMBAHASAN}

Pengabdian kepada masyarakat adalah suatu kegiatan yang dilaksanakan dalam upaya untuk dapat memberikan dampak positif bagi pengembangan sumber daya manusia baik dari segi wawasan, pengetahuan dan keterampilan. Melalui kegiatan ini Institut Komunikasi dan Bisnis LSPR sebagai perguruan tinggi turut memberikan peran nyata bagi para pelaku Usaha Mikro, Kecil dan Menengah (UMKM) di Desa Tridaya Sakti, Kecamatan Tambun Selatan, Kabupaten Bekasi.

Pada masa pandemi saat ini, Pemerintah sedang menggencarkan gerakan literasi digital ke semua lapisan masyarakat. Kementerian Komunikasi dan Informatika meluncurkan Program Literasi Digital Nasional "Indonesia Makin Cakap Digital" sebagai upaya percepatan transformasi digital nasional khususnya terkait pengembangan sumber daya manusia (SDM) digital (Tempo.co, 2021). Tak dapat dipungkiri pemahaman teknologi dan kecakapan digital sangat dibutuhkan sebagai langkah mempertahankan eksistensi di masa pandemi. Lingkup yang juga menjadi sasaran literasi digital adalah UMKM. Menteri Keuangan Sri Mulyani Indrawati mengungkapkan pandemi merupakan momentum akselerasi transformasi digital, sektor Usaha Mikro, Kecil, dan Menengah menjadi salah satu sektor yang beradaptasi di masa pandemi. Sektor ini beralih ke platform dan pasar digital agar dapat melayani konsumen (Kementerian Keuangan Republik Indonesia, 2021).

Salah satu pilar kesuksesan UMKM adalah strategi komunikasi pemasaran yang dilakukan. Adi Ariantara, Kepala Dinas Koperasi, Usaha Kecil dan Menengah serta Perdagangan (KUKMP) DKI Jakarta mengatakan "Melalui strategi pemasaran yang baik posisi UKM menjadi kuat dan patut diperhitungkan dalam kegiatan ekonomi nasional dan akhirnya membawa keuntungan bagi usaha tersebut. Selain itu, dapat bersaing dan berkembang dalam kegiatan ekonomi nasional" (Tobing, 2019). Digitalisasi menggiring komunikasi pemasaran UMKM menuju level yang lebih tinggi, lebih luas, cepat, efektif dan efisien. Untuk itu Institut Komunikasi dan Bisnis LSPR mengadakan Workshop "Komunikasi Pemasaran Digital bagi UMKM Desa Tridaya Sakti sebagai wujud percepatan literasi digital UMKM di Kabupaten Bekasi”.

Workshop yang dilakukan secara online ini mengusung judul "Komunikasi Pemasaran Usaha dan Jasa Melalui Media Sosial pada Kelompok Usaha di Desa Tridaya Sakti”. Diharapkan melalui workshop ini para peserta UMKM lebih mengetahui peran nyata media sosial bagi pelaku UMKM, termasuk manfaat menggunakan sosial media bagi UMKM dan pilihan media sosial apa saja yang dapat digunakan. Komunikasi pemasaran melalui media sosial memiliki peranan penting, cakupannya yang luas akan mempermudah para pengusaha UMKM untuk mencapai konsumennya yang jauh terlebih lagi saat pandemi dan pemberlakuan pembatasan kegiatan masyarakat (PPKM) seperti saat ini, dengan media sosial pengusaha juga dapat berkreasi menciptakan konten dan memberikan informasi yang menarik kepada calon pelanggan/pembeli dengan memanfaatkan fitur-fitur 
di media sosial. Dengan demikian calon konsumen akan lebih mudah menemukan produk/jasa dan tertarik untuk membeli produk (iBrand.id, 2020).

Jenis usaha para peserta UMKM beragam seperti fashion, sembako, barang bekas, pedagang buah-buahan, kue dan aneka makanan, minuman herbal, jasa percetakan dan jasa service AC. Dari peserta UMKM yang hadir diminta mengisi pre-test untuk meninjau pengetahuan dan kesadaran peserta UMKM mengenai pemanfaatan media sosial sebagai media komunikasi pemasaran produk/jasa mereka.

Bagi sebagian besar peserta Workshop Komunikasi Pemasaran Digital bagi UMKM Desa Tridaya Sakti sebagai wujud literasi digital UMKM di Kabupaten Bekasi ini adalah kegiatan workshop perdana yang mereka ikuti secara online. Mayoritas dari peserta belum pernah mengikuti kegiatan seperti ini sebelumnya, namun $73 \%$ peserta tetap merasa nyaman dengan kegiatan yang dilakukan secara online ini dan lebih memilih workshop secara online karena dinilai lebih efektif.

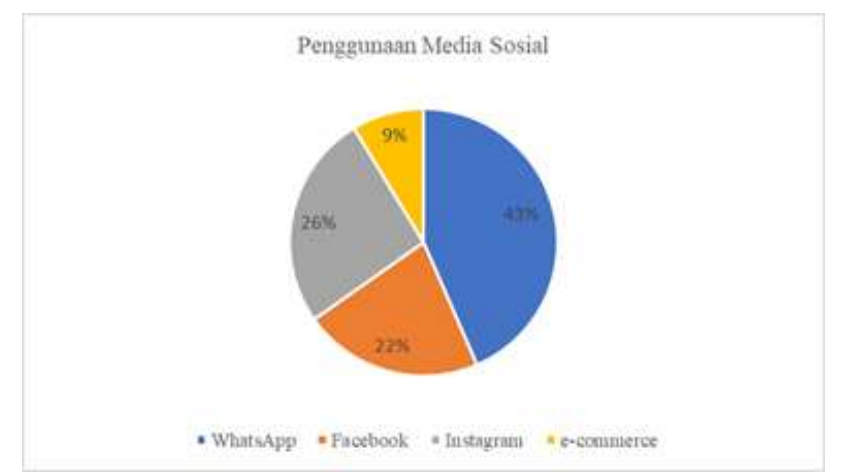

Grafik 1. Media sosial yang digunakan peserta UMKM

Mayoritas peserta UMKM
menggunakan media sosial sebagai media
komunikasi pemasaran usaha mereka sebelum
mengikuti workshop. WhatsApp menempati urutan
pertama yang paling banyak digunakan yaitu
sebesar $43 \%$ dilanjutkan dengan Instagram $26 \%$,
Facebook $22 \%$ dan e-commerce sebesar 9\%. Dari
survei yang dilakukan Paxel bekerja sama dengan
lembaga survei Provetics juga menunjukkan bahwa
UKM berbasis online di Indonesia lebih

mengandalkan media sosial dibandingkan situs $e$ commerce untuk memasarkan barang dagangannya, WhatsApp merupakan platform media sosial yang paling banyak digunakan oleh UMKM berbasis online, yakni mencapai 84 persen. Kemudian disusul oleh Instagram sebanyak 81 persen dan Facebook mencapai 36 persen (Riyanto, 2019). Hasil ini menunjukkan bahwa sebelum mengikuti workshop online, para peserta UMKM sudah memiliki pengetahuan tentang media sosial dan sudah mulai berupaya memanfaatkan media sosial tersebut untuk menunjang kegiatan usaha mereka khususnya dalam hal pemasaran.

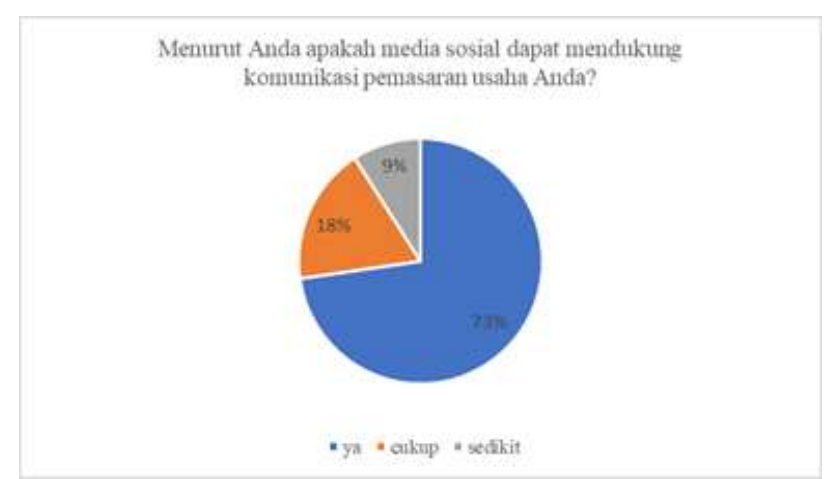

Grafik 2. Media sosial mendukung komunikasi pemasaran

Para peserta UMKM sudah memiliki kesadaran bahwa media sosial dapat mendukung pemasaran produk/jasa mereka. $73 \%$ setuju akan hal tersebut karena dirasa saat ini sudah banyak masyarakat yang memiliki akses untuk menggunakan media sosial, selain itu media sosial dapat menjangkau pasar yang lebih jauh, lebih cepat untuk mempromosikan produk/jasa kepada pembeli. Kementerian Koperasi dan Usaha Kecil Menengah (Kemenkop UKM) melansir sebanyak 3,79 juta usaha mikro, kecil, dan menengah (UMKM) sudah memanfaatkan platform online dalam memasarkan produknya (Ayuwuragil, 2017). Walau demikian masih ada peserta yang merasa media sosial hanya akan mendukung bagi mereka yang memahami dan hanya membantu sedikit sejauh ini.

Sampai saat ini kendala yang sering dialami ketika menggunakan media sosial sebagai sarana pemasaran usaha adalah kurangnya peralatan, 
minimnya koneksi, kurangnya pemahaman dalam menggunakan media sosial itu sendiri, keterbatasan keterampilan dalam menghasilkan foto produk yang estetik, gagap teknologi, kecenderungan konsumen ingin melihat produknya secara langsung, persaingan harga pada marketplace, hingga ketidakpercayaan konsumen terhadap penjualan online karena masih maraknya penipuan yang terjadi melalui media sosial.

Pada akhir sesi workshop melalui media online ini, peserta kembali diminta mengisi post-test dengan tujuan untuk mengetahui pemahaman dan action (tindakan) yang akan dilakukan para peserta UMKM terkait dengan isi materi.

Setelah mengikuti workshop, apakah Anda mengetahui dan memahami manfaat komunikasi pemasaran melalui media sosial?

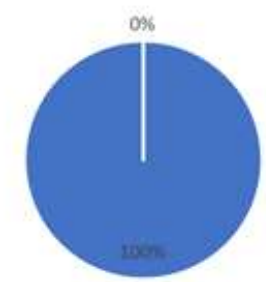

- grtali memahami - belum menahtami

Grafik 3. Pemahaman manfaat komunikasi pemasaran melalui media sosial

Setelah kegiatan workshop berakhir, seluruh peserta telah mengetahui dan memahami pentingnya media sosial dalam mendukung kegiatan komunikasi pemasaran UMKM, termasuk jenis media sosial apa saja yang dapat digunakan dalam usaha, contoh UMKM yang telah berhasil menggunakan media sosial untuk meningkatkan omset penjualan, hal-hal apa saja yang harus dipersiapkan sebagai konten di media sosial dan lainnya.
Setelah mengikuti workshop, apakah Anda akan menggunakan media sosial sebagai media komunikasi pemasaran usaha Anda?

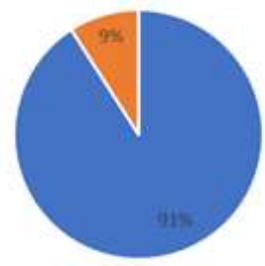

*akan menggunakan - tidak

Grafik 4. Penggunaan media sosial setelah workshop

Ada $91 \%$ responden menyatakan akan lebih giat menggunakan media sosial ke depannya termasuk akan mempelajari lebih lanjut cara menggunakan media sosial dan cara membuat konten media sosial yang menarik dengan tujuan untuk menunjang dan memudahkan promosi atau pemasaran produk/jasa. Beberapa di antaranya juga akan mulai mempelajari media sosial lainnya yang belum pernah digunakan sebelumnya. Saat ini pengguna media sosial di Indonesia sangat banyak, daya beli melalui online juga tinggi sehingga memberikan peluang yang lebih besar bagi UMKM.

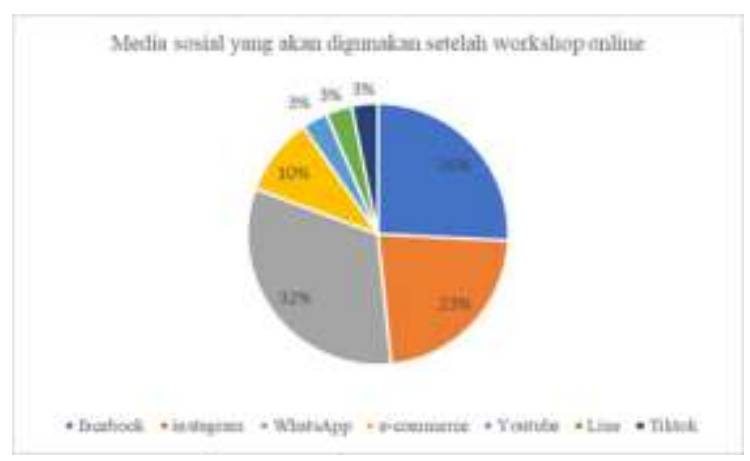

Grafik 5. Media sosial yang akan digunakan

WhatsApp $32 \%$ dan facebook $26 \%$ menempati 2 urutan utama yang dipilih peserta UMKM untuk menunjang kegiatan komunikasi pemasaran mereka ke depannya. Dilanjutkan dengan Instagram sebesar 23\%, dan mulai masuk ke e-commerce sebesar $10 \%$. Jenis media sosial yang lebih variatif juga dipilih oleh beberapa peserta 
yaitu YouTube, Line dan TikTok masing-masing $3 \%$.



Grafik 6. Media sosial yang digunakan sebelum dan sesudah workshop

Grafik di atas menunjukkan para peserta berminat untuk menambah platform media sosial yang belum digunakan, Facebook yang awalnya hanya digunakan oleh 5 peserta menjadi 8 peserta UMKM, begitu pula peminat Instagram dan $e$ commerce bertambah 1 peserta. Artinya setelah pemaparan materi workshop peserta memiliki keinginan dan akan menambah media sosial yang digunakan untuk menunjang komunikasi pemasaran produk/jasa mereka sebagai tindakan nyata (action).

Setelah mendengarkan pemaparan materi workshop online mengenai Komunikasi Pemasaran Usaha dan Jasa Melalui Media Sosial, sebesar 64\% peserta telah mengetahui cara menangani kendala yang mereka alami dalam menggunakan media sosial untuk komunikasi pemasaran. Namun masih ada peserta sekitar $36 \%$ belum menemukan solusi bagi kendala mereka.

Tabel 1. Kendala penggunaan media sosial dan solusi

\begin{tabular}{|l|c|}
\hline \multicolumn{1}{|c|}{ Kendala } & Solusi \\
\hline Foto produk, promosi & Sudah mengetahui \\
\hline Kurang memahami cara memasarkannya & Sudah mengetahui \\
\hline $\begin{array}{l}\text { Foto kurang bagus, pembeli lebih memilih } \\
\text { melihat barangnya langsung }\end{array}$ & Sudah mengetahui \\
\hline $\begin{array}{l}\text { Kurang memahami konten yang ada di } \\
\text { media tersebut }\end{array}$ & Belum mengetahui \\
\hline Kurang menguasai media sosial & Belum mengetahui \\
\hline Gaptek (gagap teknologi) & Sudah mengetahui \\
\hline Tidak mempunyai peralatan & Sudah mengetahui \\
\hline Koneksi, dan penipuan dalam penjualan & Belum mengetahui \\
\hline Menurut saya tidak ada kendala & Sudah mengetahui \\
\hline Ketidakpercayaan customer karena lewat & Belum mengetahui \\
\hline
\end{tabular}

media sosial juga sering ada mafia

Ketika ada gangguan jaringan

Sudah mengetahui

Tabel di atas menunjukkan beberapa hambatan penggunaan media sosial untuk komunikasi pemasaran seperti, foto produk, cara pemasaran, peralatan yang dibutuhkan, hal-hal terkait koneksi dan masih minimnya pengetahuan tentang teknologi (gagap teknologi) sudah mendapatkan solusi dari materi workshop online ini. Walaupun demikian $36 \%$ belum mendapatkan solusi atas kendala mereka yang meliputi kurangnya pemahaman dan penguasaan konten media sosial, penipuan dalam penjualan online yang marak terjadi sehingga membuat konsumen lebih selektif dan tidak percaya begitu saja pada penjualan online di media sosial.

Kegiatan pengabdian masyarakat ini mendorong para pelaku UMKM untuk melakukan komunikasi pemasaran digital dengan memanfaatkan media sosial sebagai media pemasaran. Kegiatan ini sebagai wujud literasi digital UMKM. Seluruh peserta menyatakan mendapatkan manfaat dari kegiatan pengabdian masyarakat seperti ini, dan banyak informasi baru yang belum mereka tahu menjadi pengetahuan baru yang dapat diaplikasikan bagi peserta dalam workshop online ini.

\section{KESIMPULAN}

Kegiatan workshop secara online dengan tema komunikasi pemasaran melalui media sosial ini merupakan bentuk dukungan kepada gaungan Gerakan Literasi Digital oleh pemerintah serta juga dukungan terhadap para pelaku UMKM di Desa Tridaya Sakti, Kecamatan Tambun, Kabupaten Bekasi, bekerja sama dengan Dinas Koperasi dan Usaha Kecil Menengah daerah setempat, terutama dalam situasi pandemi seperti sekarang ini.

Kegiatan ini bertujuan agar ada semakin banyak pelaku UMKM dari Desa Tridaya Sakti untuk memulai beralih ke komunikasi pemasaran secara digital melalui media sosial. Tujuan ini sudah

Teknologi Informasi dan Komunikasi 36 
tercapai, ditunjukkan dari adanya $91 \%$ dari peserta UMKM yang merespons akan mulai menggunakan media sosial sebagai sarana komunikasi pemasaran setelah mengikut kegiatan workshop online ini.

Namun, adanya kendala yang dihadapi oleh para pelaku UMKM ini yang mereka akui belum mendapatkan solusinya dari kegiatan workshop secara online ini. Ada $36 \%$ peserta UMKM yang menjawab bahwa mereka belum mendapatkan solusi dari kendala yang mereka alami dari workshop online yang diadakan. Banyak dari kegiatan-kegiatan ini bersifat keterampilan tambahan terkait penggunaan media sosial itu sendiri. Beberapa kendala tersebut di antaranya adalah kurangnya pemahaman akan konten yang ada di media sosial, kurang menguasai media sosial, dan juga ketidakpercayaan pelanggan akan transaksi melalui media sosial karena adanya oknum yang menyalahgunakan media sosial untuk tindak penipuan.

Berdasarkan hasil survei terhadap para peserta UMKM tersebut dapat disimpulkan bahwa perlu adanya kegiatan lanjutan untuk membantu para pelaku UMKM ini. Oleh karena itu, Institut Komunikasi dan Bisnis LSPR juga mengadakan kegiatan lanjutan untuk kegiatan literasi digital terkait komunikasi pemasaran melalui media sosial ini dalam bentuk mengajak mahasiswa LSPR yang juga mengikuti kegiatan workshop online ini untuk membantu pelaku UMKM dari desa Tridaya Sakti ini dalam pembuatan rancangan rencana komunikasi pemasaran media sosialnya yang mana dikemas dalam bentuk lomba atau kompetisi.

Dari evaluasi kegiatan workshop melalui media online dengan judul "Komunikasi Pemasaran Usaha dan Jasa Melalui Media Sosial pada Kelompok Usaha di Desa Tridaya Sakti” ini dapat disimpulkan bahwa kegiatan berjalan sukses dan juga berhasil dalam mencapai tujuan kegiatannya. Adapun kendala-kendala yang masih dihadapi oleh para peserta UMKM dalam penggunaan media sosial dapat diatasi dengan adanya kegiatan lanjutan yang melibatkan mahasiswa LSPR untuk membantu para pelaku UMKM ini agar tujuan dari Gerakan Literasi Desa ini semakin efektif. Namun, seberapa efektif kegiatan lanjutan ini perlu nantinya dievaluasi tersendiri dan ditelaah lebih lanjut.

\section{UCAPAN TERIMAKASIH}

Terima kasih kepada Kepala Bidang Pemberdayaan Usaha Mikro Dinas Koperasi dan UKM Kabupaten Bekasi, Bapak Agus Dwi Riyanto, ST, M.Si sebagai narasumber eksternal. Juga kepada Narasumber internal, Bapak Resiyaman Patrick Oratmangun, MIB dosen Fakultas Bisnis Institut Komunikasi dan Bisnis - LSPR. Selain itu juga kepada Kepala Desa Tridaya Sakti, Bapak Suwardi Wada, SE beserta UMKM Desa Tridaya Sakti dan Bapak Drs. H. Iyan Priyatna, M.Si selaku Kepala Dinas Koperasi Usaha Kecil dan Menengah Kabupaten Bekasi atas dukungannya. Ucapan terima kasih juga disampaikan kepada Institut Komunikasi dan Bisnis LSPR melalui Lembaga Penelitian dan Pengabdian Masyarakat. Semoga Pengabdian seperti ini bisa terus dilakukan di kemudian hari sebagai kontribusi akademi kepada masyarakat.

\section{REFERENSI}

5 Manfaat Pemasaran Melalui Media Sosial (n.d.). Diambil dari https://ibrand.id/manfaatpemasaran-melalui-media-sosial/

Arianto, B. (2021). Pengembangan UMKM Digital di Masa Pandemi Covid-19. ATRABIS: Jurnal Administrasi Bisnis (e-Journal), 6(2), 233247. https://doi.org/10.38204/atrabis.v6i2.512

Ayuwuragil, K. (2017). Kemenkop UKM: 3,79 Juta UMKM Sudah Go Online. Diambil dari https://www.cnnindonesia.com/ekonomi/201711151 61037-78-255819/kemenkop-ukm-379-juta-umkmsudah-go-online/

Budiarto, R., Susetyo Hario Putero, Hempri Suyatna, Puji Astuti, Harwin Saptoadi, M. Munif Ridwan, Bambang Susilo D. (2015). Pengembangan UMKM Antara Konseptual dan Pengalaman Praktis. Gadjah Mada University Press. Yogyakarta.

Kementerian Keuangan Republik Indonesia. (2021). Menkeu: Pandemi merupakan 
Momentum Akselerasi Transformasi Digital. Diambil dari https://www.kemenkeu.go.id/publikasi/berita/menke u-pandemi-merupakan-momentum-akselerasitransformasi-digital/

Kementerian Komunikasi dan Informatika Republik Indonesia. (2021, April 16). Menteri Johnny Luncurkan Gerakan Nasional Literasi Digital untuk 12,4 Juta Masyarakat [Siaran Pers]. Diambil dari https://kominfo.go.id/content/detail/33924/siaranpers-no123hmkominfo042021-tentang-menterijohnny-luncurkan-gerakan-nasional-literasi-digitaluntuk-124-juta-masyarakat/0/siaran_pers

Prasetyawati, Y. R., Setyaningtyas, E., Ayu, J. P., Sartika, K. D., Adithia, S. (2021). Pelatihan Culinary Entrepreneur Dalam Mengembangkan Kinerja UMKM di Masa Pandemi. Journal of Servite, 3(1), 31-43. https://doi.org/10.37535/102003120213

Riyanto, G. P. (2019). Survei: UKM Lebih Suka Jualan Via Media Sosial, WhatsApp Teratas. Diambil dari https://tekno.tempo.co/read/1255029/survei-ukmlebih-suka-jualan-via-media-sosial-whatsappteratas/full\&view $=$ ok

Santia, T. (2020). Berapa Jumlah UMKM di Indonesia? Ini Hitungannya. Diambil dari https://www.liputan6.com/bisnis/read/4346352/bera pa-jumlah-umkm-di-indonesia-ini-hitungannya

Sari, S. M., Yunizar, \& Sartika, D. (2020).
Penentu Keunggulan Bersaing Pada UMKM : Apakah Kompetensi Digital dan Orientasi Kewirausahaan Penting?. AdBispreneur: Jurnal Pemikiran dan Penelitian Administrasi Bisnis dan Kewirausahaan, 5(1), 63-72. https://doi.org/10.24198/adbispreneur.v5i1.26999

Sasmito, Y. W. D., \& Prestianto, B. (2021). Analisis Tingkat Literasi Digital Dan Penerapan ECommerce Pada Usaha Mikro Kecil Dan Menengah Di Kota Semarang. JEMAP: Jurnal Ekonomi Manajemen, Akuntansi dan Perpajakan, 4(1), 145162. https://doi.org/10.24167/jemap.v4i1.3148

Tambunan, T. (2012). Usaha Mikro Kecil dan Menengah di Indonesia: Isu-Isu Penting. LP3ES. Jakarta 2012

Tempo.co. (2021). Presiden Jokowi Luncurkan Program Literasi Digital Nasional. Diambil dari https://nasional.tempo.co/read/1464211/presidenjokowi-luncurkan-program-literasi-digitalnasional/full\&view $=$ ok

Tobing, A. G. L. (2019). Dinas KUKMP Adakan Pelatihan Pemasaran dan Komunikasi Bisnis Bagi UKM. Diambil dari https://www.beritajakarta.id/read/70767/dinaskukmp-adakan-pelatihan-pemasaran-dankomunikasi-bisnis-bagi-ukm\#.YUBtcn0xXb1

We are social. (2021). Digital 2021. Diambil dari https://wearesocial.com/digital-2021 